\title{
Malnutrition in African adults
}

\section{Effect of diet on body composition}

\author{
By E. G. HOLMES*, E. R. JONES, MARGARET D. LYLE* \\ AND MARGARET W. STANIER \\ Department of Physiology and R/I44 Research Unit, Makerere College, \\ Kampala, Uganda \\ (Received 3 Fanuary 1956)
}

In the course of a long-term study of the nitrogen balance of African subjects who had previously consumed for a long time a diet very low in protein, we observed no correspondence between the gain in weight during rehabilitation on a high-protein, highcalorie diet and the gain to be expected from the observed retention of nitrogen (Holmes, Jones \& Stanier, I954).

Our calculations of tissue gain were based on the assumption that the nitrogen retained was converted into protein, and that the building of this protein into tissue would involve the deposition of two parts of water to one part of protein. On the more probable assumption that the retention of $\mathrm{I} g$ nitrogen would involve the deposition of $30 \mathrm{~g}$ tissue (Edelman, Olney, James, Brooks \& Moore, 1952), the discrepancy between the observed and expected weight changes would be considerably greater.

If nitrogen is retained by the body without corresponding gain in weight, some other body constituents must have been lost. Such loss might be of water, fat, or minerals; of these the most probable is water. Indeed it is well known that undernourished persons frequently show an increase in extracellular fluid, to the point of displaying gross oedema, and that during rehabilitation the excess of fluid disappears, often with demonstrable loss of body-weight, in spite of a high calorie and protein intake. We determined extracellular fluid by the thiocyanate method, and demonstrated that it was initially high, and that it later decreased. But we have found that the changes, though very considerable, were in fact quite insufficient to account for the discrepancies between expected and observed changes in body-weight. We have tried to solve the problem by three separate lines of approach.

(I) We have followed changes in body composition by determining total body water and extracellular water by dilution methods.

(2) We have determined balances of nitrogen, sulphur, phosphorus, calcium, potassium and calories with the threefold object of making sure that sulphur and phosphorus as well as nitrogen were retained in the body, that there was no defect in absorption, and to discover whether potassium was being excreted or retained.

(3) We have studied the water and protein content of muscle tissue obtained at autopsy or operation.

* Present address: East African Medical Survey and Research Institute, Mwanza, Tanganyika. 
Since these three methods of attack involve very different techniques, we present our results in three separate parts.

\section{PART 1. DETERMINATION OF BODY COMPOSITION}

\section{The validity of the methods available}

Several methods have been used for the determination of total body water, extracellular water and, by difference, intracellular water. If the percentage of water in tissues is known or assumed, figures can be calculated for cell mass and minerals and, of course, the difference between the body-weight and the sum of the extracellular fluid, cell mass, and minerals, will represent the fat other than that which is a constituent of the cell mass. The composition of the bodies of human subjects has been assessed by this technique (McCance \& Widdowson, 195I). The accuracy of this assessment depends first upon the accuracy of the methods used for determining total body water and extracellular water and, secondly, upon the validity of the assumptions underlying the calculation of minerals and, more particularly, of cell mass.

Water labelled with deuterium or with tritium, urea and phenazone, have all been used to determine total body water by dilution. In addition, body water can be calculated from measurements of body density.

Total body water, expressed as a percentage of body-weight, must clearly vary inversely with the amount of body fat. Determinations of body water in different individuals cannot, therefore, be expected to give similar results, unless a correction for the amount of fat can be made or unless, as is often done, water is expressed as a percentage of lean body-weight. If, however, the means of measurements made on groups of normal individuals are compared, it is reasonable to expect that the various methods of measuring body water should give similar results.

Table I gives the mean values for total body water published for the different methods, with the number of individuals in each group. It can be calculated from it that for males the weighted mean value of all the determinations with water labelled with deuterium is $6 \mathrm{I} \cdot 2 \%$ of body-weight. The weighted mean value for determinations with urea is $60.6 \%$, for determinations by body density $54.3 \%$, and with phenazone $53.0 \%$. The sex of the subjects used for body-density determinations is not stated, and this measurement involves an assumption about the water content of the soft tissues. The dilution methods do not. Taking into account the fact that the amount of body fat was not accurately known in any of the subjects, it seems fair to conclude that measurements with urea and water labelled with deuterium give substantially the same results, but that measurements with phenazone may give lower values.

All these methods have been criticized on various grounds. 'The consensus of opinion, however, seems to be that the heavy-water method is least open to theoretical and technical objection. Since, however, similar results are obtained by the use of urea, equal validity may be claimed for it and its use may be considered justified.

Several methods have been used for the measurement of extracellular fluid, against all of which, again, objection has been made on theoretical grounds. Sodium thiocyanate (Lavietes, Bourdillon \& Klinghofer, I936), sodium thiosulphate (Cardozo \& 
Edelman, 1952), bromide (Brodie, Brand \& Leshin, I939), inulin (Gaudino, Schwartz \& Levitt, I948), sucrose (Deane, Schreiner \& Robertson, 195I) have all been used. It seems generally agreed that sodium thiocyanate, which has probably been most widely used, gives higher results than the other methods. It is known to enter red blood cells. A correction can be applied, but naturally the suspicion arises that it may

\section{Table I. Values previously reported for total body water in man}

\begin{tabular}{|c|c|c|c|c|}
\hline Method & Authors & & & $\begin{array}{l}\text { Total body water } \\
\text { as percentage } \\
\text { of body-weight }\end{array}$ \\
\hline $\begin{array}{l}\text { Water labelled with } \\
\text { deuterium }\end{array}$ & Edelman et al. (1952) & $\begin{array}{l}\text { M. } \\
\text { F. }\end{array}$ & $\begin{array}{l}27 \\
19\end{array}$ & $\begin{array}{l}62 \cdot 0 \\
51 \cdot 5\end{array}$ \\
\hline $\begin{array}{l}\text { Water labelled with } \\
\text { deuterium }\end{array}$ & $\begin{array}{l}\text { Soberman, Brodie, Levy, Axelrod, } \\
\text { Hollander \& Steele (I949) }\end{array}$ & $\begin{array}{l}\mathrm{M} \\
\mathrm{F}\end{array}$ & $\begin{array}{l}6 \\
2\end{array}$ & $\begin{array}{l}55 \cdot 7 \\
46 \cdot 1\end{array}$ \\
\hline $\begin{array}{l}\text { Water labelled with } \\
\text { deuterium }\end{array}$ & Hevesy \& Hofer (I934) & M. & I & $63 \cdot 0$ \\
\hline $\begin{array}{l}\text { Water labelled with } \\
\text { tritium }\end{array}$ & $\begin{array}{l}\text { Pace, Kline, Schachman \& Harfenist } \\
(1947)\end{array}$ & M. & I & $64 \cdot 7$ \\
\hline Urea & McCance \& Widdowson (I95I) & $\begin{array}{l}\text { M. } \\
\text { M. }\end{array}$ & $\begin{array}{r}6 \\
10\end{array}$ & $\begin{array}{l}60 \cdot 5^{*} \\
57 \cdot 2 \dagger\end{array}$ \\
\hline Urea & Widdowson \& McCance (I95r) & M. & 5 & $6 \mathrm{x} \cdot 8 \dagger$ \\
\hline Urea & $\begin{array}{l}\text { Nutrition Research Laboratories, Coonoor } \\
\text { (1954) }\end{array}$ & M. & 8 & $64: 3$ \\
\hline Specific gravity & Soberman et al. (1949) & & $9 f$ & $54: 3$ \\
\hline Phenazone & $\begin{array}{l}\text { Steele, Berger, Dunning, Brodie \& Klein } \\
\text { (1950) }\end{array}$ & $\begin{array}{l}\text { M. } \\
\text { F. }\end{array}$ & $\begin{array}{l}5 I \\
3 I\end{array}$ & $\begin{array}{l}52 \cdot 7 \\
44 \cdot 6\end{array}$ \\
\hline Phenazone & Soberman et al. (1949) & $\begin{array}{l}\text { M. } \\
\text { F. }\end{array}$ & $\begin{array}{l}6 \\
2 \\
9\end{array}$ & $\begin{array}{l}54 \cdot 3 \\
44 \cdot 4 \\
53 \cdot 9\end{array}$ \\
\hline
\end{tabular}

* In their paper, the authors give details for ten normal and obese men. We have taken the average of the first six, whose mean weight was $92.8 \%$ of the standard, which the authors have calculated from the formula of Odier \& Mach (1949).

$\dagger$ Rehabilitated Germans, ex-P.O.W.

I Sex not stated, but the subjects were the same as those used by the same authors for the phenazone method.

enter other cells as well. Scheinberg \& Kowalski ( 1950 ) claim that sodium thiocyanate is bound to serum albumin, some $30 \%$ of the thiocyanate in serum being indiffusible. It has been stated that in some pathological conditions the thiocyanate space may approximate in size to the total body water. We have not ourselves encountered such conditions. If the figures for extracellular fluid obtained with sodium thiocyanate are compared with those obtained with sodium thiosulphate, the latter are roughly $70 \%$ of the former (Ancel Keys, personal communication).

If the body constituents are determined by the method of McCance \& Widdowson (195I), for a given value for total body water, the larger the figure for extracellular fluid, the larger will be the amount of fat, since it is assumed that (total body water extracellular fluid) $\times \frac{100}{67}=$ cell mass, i.e. the body constituents except for fat and minerals. Direct observation has shown that the human body always contains some fat, and McCance \& Widdowson give a value of $16 \%$ fat for a man of standard weight 
for his height. Others have given a figure of about 10\%. McCance \& Widdowson's figures can be recalculated on a thiosulphate basis for extracellular fluid by assuming that, had thiosulphate been used instead of thiocyanate for determination of extracellular fluid, the values would have been $70 \%$ of those shown for thiocyanate. Such recalculation gives $8.9 \%$ fat for normal males, $3 \frac{1}{2} \%$ for repatriated Germans before rehabilitation and $16.2 \%$ for the same Germans after rehabilitation. Presumably the use of phenazone, instead of urea, for total body water would have raised the apparent percentage of fat. It would appear that at present it is possible to juggle with the results obtained by a number of methods in order to obtain acceptable figures, and perhaps it would be reasonable to claim that so far none of the methods available for determining body composition is sufficiently trustworthy to allow firm conclusions to be drawn. However, we suggest that determinations carried out by the urea and thiocyanate methods may at least permit valid comparisons between the same subject at different times, and therefore we present the results we have obtained by their use.

\section{EXPERIMENTAL}

Chemical methods. We have used in these observations the method of McCance \& Widdowson (195I) with the two following modifications:

(I) Urea in blood and urine was measured by the method of Archibald (1943).

(2) In most of the experiments described, the urea was administered intravenously as, even when blood samples were taken 3 or $4 \mathrm{~h}$ after the administration of urea by mouth, the urea content of the second serum sample was sometimes higher than that of the first. In such an event, distribution of urea through the tissues may not be complete, so the results had to be rejected. (It has been shown by Frazer, French, Thomas \& Thompson (1952) that in the sprue syndrome the absorption of various substances, including urea, is delayed.)

The $20 \mathrm{~g}$ urea were accurately weighed and dissolved in water in a $200 \mathrm{ml}$. weighed measuring flask. The weight of the urea solution was determined by difference and the solution was filtered and sterilized by being brought to the boil. At the beginning of the experiment the urea solution was poured into a $500 \mathrm{ml}$. separating funnel to which was attached the drip-feed of an ordinary blood transfusion set, the whole having been previously autoclaved. A little solution was run out of the drip to expel air and the whole apparatus was weighed. An adapter was subsequently fitted to the needle which had just been used to inject the thiocyanate, and which had been left in the vein. The urea solution was slowly run into the vein, the infusion of $150 \mathrm{ml}$. taking about $\mathrm{I}_{5} \mathrm{~min}$. At the end of the infusion, the whole apparatus (without the injection needle) was reweighed. The weight of the solution infused was thus accurately measured, and the dose of urea could easily be calculated. It amounted to ro-r $7 \mathrm{~g}$.

Subjects. We carried out determinations of body composition on a number of normal subjects: five Europeans, seven African students and one African hospital patient considered to be normal. Three separate determinations were made on one of the Europeans.

Since the method, in our hands, gave results in reasonable agreement with those of other workers, we applied it to measure the change in eight malnourished male African 
subjects after feeding on a high-protein, high-calorie diet. The condition of this type of subject when admitted to hospital has been previously discussed (Holmes et al. I954) and need not be described at length here. All showed clinical oedema, with a moderate degree of anaemia. One (Mariko) had gross ascites, and had been diagnosed as suffering from hepatic cirrhosis. This diagnosis was not supported by liver biopsy, and the ascites eventually cleared. He had (and still has) gross splenomegaly. Another (Naigesente) had been the subject of previous balance studies (Holmes et al. 1954). He returned to hospital acutely ill, and was found to have typhoid fever. The determination was carried out on him when he was clinically convalescent and about to be discharged. No second determination was possible as he did not remain in hospital.

A series of six determinations of body composition was carried out on a single African patient (Simoni). On admission, this subject was oedematous, but was not in nearly so precarious a state as many we had seen. Within the ist month of admission, his weight dropped by $8.5 \mathrm{~kg}$ and then rose fairly steeply. It was still rising when the first determination was made, and clinically he was improving fast. ACTH and cortisone were administered during his recovery (actually for the purpose of a different investigation) and body composition was determined before and after the administration of these hormones.

\section{RESULTS}

The results of determinations of body composition in normal subjects are given in Table 2.

It will be observed that the figure for mean total body water in Table 2 is $64 \%$ of the body-weight, which is somewhat higher than McCance \& Widdowson's (I95 I)

Table 2. Body-weight and body composition of control subjects

\begin{tabular}{|c|c|c|c|c|c|c|c|c|c|}
\hline \multirow[b]{2}{*}{ Subject } & \multirow[b]{2}{*}{$\begin{array}{l}\text { Body- } \\
\text { weight } \\
\text { (kg) }\end{array}$} & \multirow[b]{2}{*}{$\begin{array}{l}\text { Standard } \\
\text { weight* } \\
(\mathrm{kg})\end{array}$} & \multicolumn{6}{|c|}{ Body composition expressed as percentage of body-weight } & \multirow[b]{2}{*}{$\begin{array}{l}\text { Method of } \\
\text { administration } \\
\text { of urea }\end{array}$} \\
\hline & & & $\begin{array}{l}\text { Total } \\
\text { body } \\
\text { water }\end{array}$ & $\begin{array}{l}\text { Thio- } \\
\text { cyanate } \\
\text { space }\end{array}$ & $\begin{array}{l}\text { Apparent } \\
\text { cell } \\
\text { mass }\end{array}$ & Minerals & $\begin{array}{c}\text { Apparent } \\
\text { fat }\end{array}$ & $\begin{array}{l}\text { Body } \\
\text { solids }\end{array}$ & \\
\hline E.H.† & $65 \cdot 3$ & $72 \cdot 6$ & $62 \cdot x$ & - & - & - & - & $37 \cdot 9$ & By mouth \\
\hline E.H.t & $65 \cdot 3$ & $72 \cdot 6$ & $63 \cdot 1$ & - & $\ldots$ & - & - & $36 \cdot 9$ & By mouth \\
\hline E.H.† & $65 \cdot 7$ & $72 \cdot 6$ & $67 \cdot 0$ & $30 \cdot 2$ & $54^{\circ} 4$ & $4 \cdot 2$ & $9 \cdot I$ & $33^{\circ} \circ$ & Intravenously \\
\hline A.L. & $67 \cdot 0$ & $7 I \cdot 8$ & $5^{8 \cdot 2}$ & - & - & - & - & $4 I \cdot 8$ & Intravenously \\
\hline Nesbitt & $6 I \cdot 9$ & $66 \cdot 0$ & 69.0 & $24 \cdot 8$ & $66 \cdot 0$ & $6 \cdot 8$ & $2 \cdot 4$ & $3 I \cdot 0$ & By mouth \\
\hline Kiryabwire & $65 \cdot 9$ & 70.4 & $60 \cdot 5$ & $23 \cdot 8$ & $54^{\circ} 9$ & $5 \cdot 9$ & $12 \cdot 4$ & 39.5 & By mouth \\
\hline Rutebarika & $68 \cdot 2$ & $71 \cdot 3$ & $65 \cdot 3$ & $17 \cdot 0$ & $72 \cdot 1$ & $5 \cdot 6$ & $5 \cdot 4$ & 347 & By mouth \\
\hline Kityo & $65 \cdot 5$ & $71 \cdot 8$ & $66 \cdot 8$ & $31 \cdot 8$ & $67 \cdot 2$ & 6.7 & $4 \cdot 3$ & $33 \cdot 2$ & By mouth \\
\hline Mwanukuzi & $65 \cdot I$ & $69 \cdot 2$ & $66 \cdot 7$ & $27 \cdot 7$ & $6 I \cdot 7$ & $6 \cdot 8$ & $2 \cdot 0$ & $33 \cdot 3$ & By mouth \\
\hline Alhad & $57 \cdot 3$ & $67 \cdot 0$ & $57 \cdot 8$ & 19.5 & $57 \cdot 2$ & $5 \cdot 7$ & $17 \cdot 6$ & $42 \cdot 2$ & By mouth \\
\hline Baingana & 56.8 & $63 \cdot 2$ & 65.7 & 25.7 & $59 \cdot 2$ & $6 \cdot 3$ & $8 \cdot 6$ & $34 \cdot 3$ & By mouth \\
\hline M.D.T. (F.) & $57 \cdot 8$ & $66 \cdot 7$ & $64 \cdot 3$ & 23.5 & $35^{\cdot 2}$ & $3 \cdot 6$ & $9 \cdot 0$ & $35 \cdot 7$ & Intravenously \\
\hline J.G. (F.) & 59.5 & $60 \cdot 4$ & 65.0 & $22 \cdot 5$ & $5 \mathrm{I} \cdot \mathrm{I}$ & $3 \cdot 8$ & $7 \cdot 7$ & $35^{\circ} \circ$ & By mouth \\
\hline M.W.S. (F.) & $52 \cdot 0$ & $55^{\circ} 6$ & 644 & $\ldots$ & - & - & - & $35^{\circ} 6$ & By mouth \\
\hline Mukasa & $6 I \cdot I$ & $6 r \cdot 3$ & 645 & $28 \cdot 0$ & 54.5 & $6 \cdot 2$ & I I 3 & $35 \cdot 5$ & Intravenously \\
\hline Mean & $62 \cdot 3$ & $67 \cdot 5$ & $64 \cdot 0$ & 24.0 & $57 \cdot 6$ & $5 \cdot 6$ & $8 \cdot 2$ & $36 \cdot a$ & \\
\hline
\end{tabular}


figure of $60.5 \%$ (their Table 7 ). However, the mean weight of our subjects $(62 \cdot 3 \mathrm{~kg}$ ) was only $92.4 \%$ of their standard weight, whereas the mean weight of McCance \& Widdowson's was $93.6 \%$ of standard. Since their subjects, therefore, had a little more fat than ours, our figure for body water might be expected to be a little higher than theirs. On the other hand, our figure is almost identical with that $(64.3 \%)$ from the Nutrition Research Laboratories, Coonoor (1954), where studies were made on apparently normal male Indians of the poorer, though not of the poorest, class. Their mean weight was $50 \mathrm{~kg}$, considerably lower than that of our subjects. As their heights are not given, the standard weights cannot be calculated. The mean value for fat was I I $.0 \%$ of the body-weight. In any event, the series are all too small for such variations in the mean values to have much significance.

Table 3 gives the results obtained for eight individuals before and after rehabilitation. 'The figure for 'apparent cell mass' depends upon the assumption that the cells contain $67 \%$ water; and the figure for cell mass in turn affects the figures for fat and for minerals. The fat is, of course, depot fat, since the fat and lipid of the tissues are necessarily included in the figure for cell mass. We have followed the example of the Coonoor workers in including a figure for body solids. It is the difference between the body-weight and the total body water and is therefore independent of any assumption as to the water content of the tissues.

Table 3 brings out the following points:

(I) In all subjects there was an increase in body solids during treatment, but it bore no obvious relationship to the body-weight which is therefore dependent also on loss or gain of water.

(2) Although in every subject there was an increase in body solids (and bodyweight) during refeeding, in the first three subjects there was actually a decrease in apparent cell mass. This finding strongly suggests that in these persons water was leaving the cells during the course of the refeeding.

(3) In the first determinations on two subjects, Matovu and Naigesente, the sum of the extracellular water, apparent cell mass, and minerals was actually greater than the body-weight, which is shown in the table as a negative value for fat. In another, Kabwa, the value for fat was so small as obviously to be within the limits of experimental error. The second determination on Matovu and the first on Mikaeri also approached these limits. Such results are plainly nonsensical and lead to such anomalies as an apparently greater increase in body fat than in total body solids.

The only conclusion to be drawn is that here at any rate the method was inapplicable. In view of our results on normal individuals and of the findings of other workers, we see no reason to attribute this to any technical cause. However, there is an obvious possible theoretical fallacy. Even if the figure of $67 \%$ for cell water is correct for normal individuals, it seems to us that it may be incorrect for some persons suffering from certain types of malnutrition. If, in such people, the water content of the cells is really greater than $67 \%$ our figure for cell mass will be exaggerated and this (erroneous) figure, plus extracellular water, plus minerals (which will also be overestimated) may actually exceed the body-weight. 


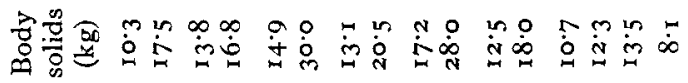

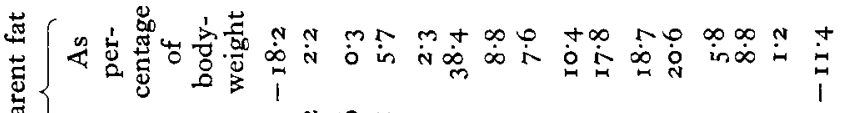

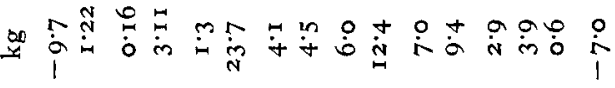

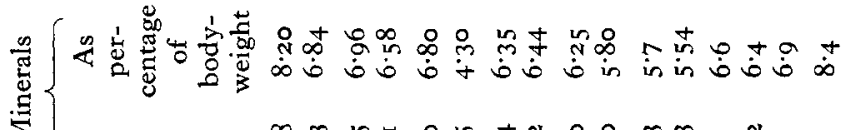

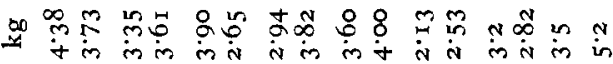

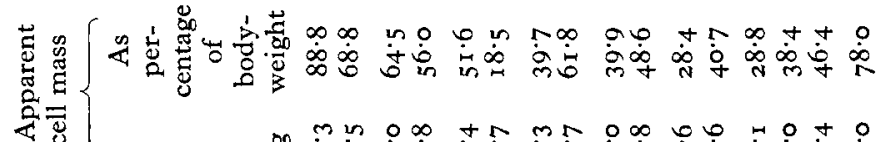
ฐं:

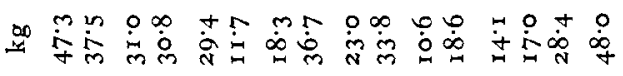

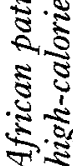
4

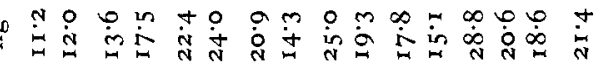

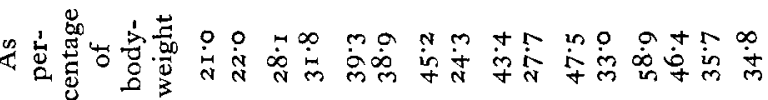

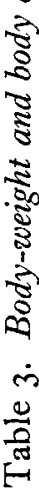

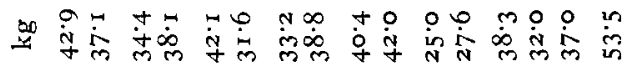

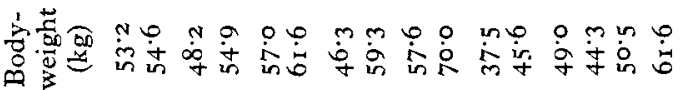

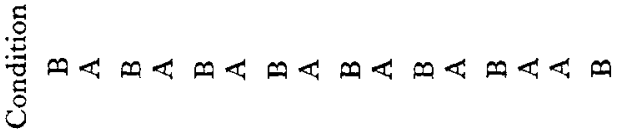
岁

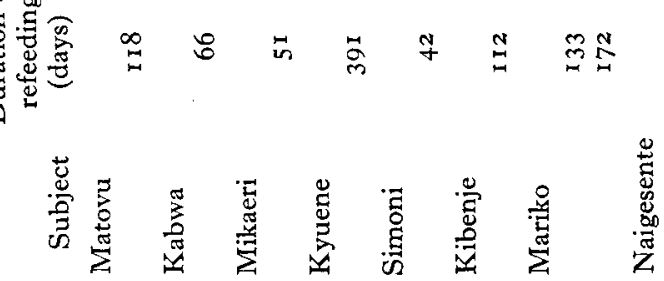


The results obtained in the series of determinations on Simoni (Table 4) throw some light on the sequence of events, and perhaps on their mechanism.

\section{Table 4. Consecutive determinations of body composition in one African} subject (Simoni)

\begin{tabular}{|c|c|c|c|c|c|c|c|c|c|c|c|c|}
\hline \multirow[b]{2}{*}{ Date } & \multirow[b]{2}{*}{$\begin{array}{c}\text { Body- } \\
\text { weight } \\
\text { (kg) }\end{array}$} & \multicolumn{2}{|c|}{$\begin{array}{l}\text { Total body } \\
\text { water }\end{array}$} & \multicolumn{2}{|c|}{$\begin{array}{c}\text { Thiocyanate } \\
\text { space }\end{array}$} & \multicolumn{2}{|c|}{$\begin{array}{l}\text { Apparent } \\
\text { cell mass }\end{array}$} & \multicolumn{2}{|c|}{ Minerals } & \multicolumn{2}{|c|}{ Apparent fat } & \multirow[b]{2}{*}{$\begin{array}{c}\text { Body } \\
\text { solids } \\
\text { (kg) }\end{array}$} \\
\hline & & $\mathrm{kg}$ & $\begin{array}{c}\text { As } \\
\text { percentage } \\
\text { of body- } \\
\text { weight }\end{array}$ & $\mathrm{kg}$ & $\begin{array}{l}\text { As } \\
\text { percentage } \\
\text { of body- } \\
\text { weight }\end{array}$ & $\mathrm{kg}$ & $\begin{array}{l}\text { As } \\
\text { percentage } \\
\text { of body- } \\
\text { weight }\end{array}$ & $\mathrm{kg}$ & $\begin{array}{l}\text { As } \\
\text { percentage } \\
\text { of body- } \\
\text { weight }\end{array}$ & $\mathrm{kg}$ & $\begin{array}{c}\text { As } \\
\text { percentage } \\
\text { of body- } \\
\text { weight }\end{array}$ & \\
\hline $\begin{array}{l}25 . \text { vi. } 54 \\
6 . \text { viii. } 54\end{array}$ & $\begin{array}{l}57 \cdot 6 \\
69 \cdot 6\end{array}$ & $\begin{array}{l}40 \cdot 4 \\
42 \cdot 0\end{array}$ & $\begin{array}{l}70 \cdot 2 \\
60 \cdot 4\end{array}$ & $\begin{array}{l}25.0 \\
19.4\end{array}$ & $\begin{array}{l}43 \cdot 4 \\
27 \cdot 7\end{array}$ & $\begin{array}{l}23 \cdot 0 \\
33 \cdot 8\end{array}$ & $\begin{array}{l}39 \cdot 9 \\
48 \cdot 6\end{array}$ & $\begin{array}{l}3 \cdot 6 \\
4 \cdot 0\end{array}$ & $\begin{array}{l}6 \cdot 25 \\
5 \cdot 80\end{array}$ & $\begin{array}{r}\mathrm{I} \cdot 0 \\
\mathrm{I} 2 \cdot 4\end{array}$ & $\begin{array}{l}10.4 \\
17 \cdot 8\end{array}$ & $\begin{array}{l}17 \cdot 2 \\
27 \cdot 6\end{array}$ \\
\hline \multicolumn{13}{|c|}{ ACTH* intramuscularly: 20 units on 30 . viii. 54,40 units on I. ix. 54} \\
\hline 6. ix. 54 & $70 \cdot 0$ & $45^{\circ} 7$ & $65 \cdot 3$ & $20 \cdot 0$ & $28 \cdot 6$ & $36 \cdot 7$ & $38 \cdot 3$ & $4 \cdot 38$ & $6 \cdot 24$ & $7 \cdot 3$ & $10 \cdot 0$ & $24 \cdot 3$ \\
\hline \multicolumn{13}{|c|}{ Cortisonet by mouth, $24 \mathrm{mg}$ 6-hourly: total $575 \mathrm{mg}$ from $2 \mathrm{I}$. ix. 54 to 26 . ix. 54} \\
\hline 26. ix. 54 & $7 I \cdot 5$ & 59.0 & & $19 \cdot 7$ & $27 \cdot 6$ & $58 \cdot 6$ & $8 r \cdot 9$ & $5 \cdot 30$ & $8 \cdot 20$ & $-12 \cdot 7$ & -17.7 & 12.5 \\
\hline 9. xi. 54 & $72 \cdot 1$ & $49^{\circ} 0$ & & $17 \cdot 7$ & $24 \cdot 6$ & $46 \cdot 7$ & $64 \cdot 8$ & & $6 \cdot 71$ & $2 \cdot 9$ & & $23 \cdot 1$ \\
\hline 17. ii. 55 & $70 \cdot 2$ & $4 \mathrm{I}^{\circ} \mathrm{O}$ & $58 \cdot 3$ & 19.2 & $3 I^{\circ} 0$ & 32.5 & $46 \cdot 3$ & 3.88 & $5 \cdot 52$ & 14.6 & $20 \cdot 8$ & $29 \cdot 2$ \\
\hline
\end{tabular}

* Cortrophin Z (Organon Laboratories, Brettenham House, Lancaster Place, London, W.C. 2). The activity of this preparation was checked by its effect on the eosinophil count of a normal control subject.

+ Cortone Acetate (Merck (North America) Inc., New York, U.S.A.).

As stated above, this patient was improving rapidly at the time when the first determination was made; and ACTH and cortisone were given at the times shown in the table. There was a marked decrease in body solids, an increase in apparent cell mass, and an apparent decrease in fat, which, after the cortisone, reached an apparent negative value. It is of interest that the patient made no complaint, and clinically appeared perfectly well. Until further data are obtained it would be premature to draw far-reaching conclusions from this result, but it does open a field for interesting speculation about the effect of the balance of the endocrine secretions on body composition.

\section{PART 2. BALANCE EXPERIMENTS}

In order to explore our problem further we have carried out a series of balance experiments. They were designed to discover, firstly, whether our subjects had any defect in absorption (if, in fact, they had been absorbing only part of the calculated calorie value of the diet, it might have had an important bearing on their changes of weight); secondly, to make sure that sulphur and phosphorus as well as nitrogen were being absorbed, as they must have been if new tissue was being formed; and thirdly, to examine the potassium balance.

The relevance of the potassium balance to the problem rests on the following argument. For the present purpose we may consider the body cells to consist of a solution of protein in an aqueous medium, in which the most plentiful positive ion is potassium, enclosed in a semi-permeable membrane. In the growing organism where cells are multiplying, both protein and potassium will be retained; retention of both protein 
and potassium will also take place during physiological hypertrophy. If, however, we are right in supposing that the cells of our subjects are at first deficient in protein which is replaced during refeeding, we should not necessarily expect a potassium retention corresponding to the protein retention. We have already implied in Part I that water leaves the cells during refeeding; but if it does, potassium may leave with it, and there might be an overall positive nitrogen balance with a diminished, or perhaps a negative, potassium balance.

\section{EXPERIMENTAL}

Subjects. The subjects were the same male African patients as described in Part I. They were admitted to the metabolic ward with malnutrition, and balance experiments were carried out during the course of their treatment with a high-protein, highcalorie diet.

Procedure. Each experiment lasted I week. An acceptable diet having been established for the patient, nine daily food rations were made up in Cellophane packs and stored deep frozen at $-20^{\circ}$. Two packs were taken at random and worked up separately for analysis in the laboratory. The experiment was begun at $8.0 \mathrm{a} . \mathrm{m}$. on the appointed day. Urine was collected from that time, and a capsule of carmine was given by mouth. Stool collection began when the carmine first appeared in the stool. At the end of the period more carmine was administered, and stool collection was continued until the carmine again appeared.

Urine and stools were collected daily and portions of daily specimens were pooled; the pooled urine, to which toluene was added, being stored at $-20^{\circ}$ until analysed.

Stools were treated as previously described (Holmes et al. 1954).

Chemical methods. The following methods were used:

Nitrogen was determined by Kjeldahl's method, with the use of selenium dioxide as a catalyst during incineration.

Total sulphur in urine and stools was determined gravimetrically by the use of the Parr peroxide bomb (Parr Instrument Co., Moline, Illinois, U.S.A.). We observed that urine samples evaporated and dried at $110^{\circ}$ as a preliminary to combustion in the bomb gave lower values for total sulphur than those dried at $70^{\circ}$, a fact suggesting the loss of a volatile sulphur compound during drying. The urine was therefore freeze-dried in the later experiments to avoid any such possible loss. Freezedried stool on the other hand gave the same value for total sulphur as stool dried at $110^{\circ}$.

It was difficult to obtain satisfactory results for the total sulphur in food with the peroxide bomb, since the maximum permissible load of the bomb used was $0.5 \mathrm{~g}$ material, and the sulphur content of the dried and powdered food residues was so low that the amount of barium sulphate obtained was too small to weigh accurately. We therefore employed the bomb calorimeter for measuring sulphur in food, using about $2 \mathrm{~g}$ dried food residue and washing out the bomb with dilute $\mathrm{HCl}$ after combustion.

Inorganic and ethereal sulphates were determined gravimetrically by Folin's method (Hawk \& Bergeim, 1926). 
Phosphate was measured by the method of King (195I) except that sulphuric acid was used in place of perchloric acid.

Potassium was measured by an adaptation from the procedures of Jacobs \& Hoffman and of Abul-Fadl for estimation of serum potassium (King, I95I, chapter 4). This method was applied to solutions of the residue obtained after complete ignition of appropriate amounts of the dried urine, food and stool in the bomb calorimeter to avoid the complications due to loss of potassium accompanying ashing in an open crucible. The residues were transferred from the bomb to volumetric flasks by washing with dilute $\mathrm{HCl}$. For urine, a known amount of solution was rendered alkaline and boiled to remove traces of ammonia found to be present. It was then made up to a known volume, and a suitable amount used for estimation. No ammonia was present in solutions from food and stool.

Calcium in food and stool was measured by the method of Schohl \& Pedley (Hawk \& Bergeim, I926, p. 784 ); the urinary calcium was estimated by Kramer $\&$ Tisdall's method for serum calcium (King, I95 I, chapter 4).

Ammonia with amino-acid nitrogen was measured by formol titration (Cole, 1928) and ammonia by distillation in a Kjeldahl apparatus.

Calories were measured by combustion of the dried residues of urine, food and stool in a Berthelot-Mahler bomb calorimeter (A. Gallenkamp and Co., I7 Sun Street, London, E.C. 2). The urine residues were extremely hygroscopic and difficult to handle; they had to be wrapped in filter-paper for insertion in the bomb, a correction for the caloric value of the filter-paper being applied. The dried stool and food were compressed into briquettes in the press provided with the apparatus. The instructions supplied with the apparatus (Gallenkamp Catalogue no. I-3100: Berthelot-Mahler Bomb Calorimeter) were followed in carrying out the technique and making the calculations. The heat equivalent of the calorimeter was determined with the pure benzoic acid supplied by the makers.

As a check on the accuracy of the bomb calorimeter the caloric values of specimens of sucrose and urea were determined. The mean of two determinations on each substance gave: sucrose $4.07 \mathrm{I} \mathrm{Cal./g,} \mathrm{urea} \mathrm{2.574} \mathrm{Cal./g.} \mathrm{The} \mathrm{figures} \mathrm{given} \mathrm{in} \mathrm{the} \mathrm{Handbook}$ of Chemistry and Physics (Chemical Rubber Publishing Company, 1949) are 3.944 and $2.526 \mathrm{Cal} . \mathrm{g}$, respectively.

Creatine with creatinine and uric acid were estimated by Folin's and Benedict's methods, respectively (King, I95 I, chapter 7 ).

\section{RESULTS}

Table 5 shows a comparison of the values found for nitrogen, sulphur, phosphorus, calcium and calories, with the corresponding values calculated from tables (Masters \& McCance, 1939; Fox \& Goldberg, 1944). The agreement appears to be reasonably good, particularly since the water content of the foodstuffs must have varied from time to time.

Tables 6 and 7 show the results of the balance experiments. The values for food are those found, not those calculated from the tables. (An earlier experiment on Simoni 
Table 5. Analysis of diets of the African subjects: calories and nutrients expressed in terms of contents of one food pack (see p. 206)

\begin{tabular}{|c|c|c|c|c|c|c|c|c|c|c|c|c|}
\hline \multirow{3}{*}{$\begin{array}{l}\text { Subject } \\
\text { Kibenje }\end{array}$} & \multirow[b]{2}{*}{ Period } & \multicolumn{2}{|c|}{ Nitrogen $(g)$} & \multicolumn{2}{|c|}{ Sulphur (g) } & \multicolumn{2}{|c|}{$\begin{array}{c}\text { Phosphorus } \\
\text { (g) }\end{array}$} & \multicolumn{2}{|c|}{ Calcium (g) } & \multicolumn{3}{|c|}{ Calories (Cal.) } \\
\hline & & Found & $\begin{array}{l}\text { Calcu- } \\
\text { lated } \\
\text { from } \\
\text { tables }\end{array}$ & Found & $\begin{array}{l}\text { Calcu- } \\
\text { lated } \\
\text { from } \\
\text { tables }\end{array}$ & & $\begin{array}{l}\text { Calcu- } \\
\text { lated } \\
\text { from } \\
\text { tables }\end{array}$ & Found & $\begin{array}{l}\text { Calcu- } \\
\text { lated } \\
\text { from } \\
\text { tables }\end{array}$ & $\begin{array}{l}\text { Potassium } \\
\text { (g) } \\
\text { Found }\end{array}$ & Found & $\begin{array}{l}\text { Calcu- } \\
\text { lated } \\
\text { from } \\
\text { tables* }\end{array}$ \\
\hline & 7 days & 182 & I 80 & $12 \cdot 2$ & $12 \cdot 0$ & 19 & 18 & $16 \cdot 7$ & 14.0 & 43 & 25,630 & 27,190 \\
\hline Kibenje & 7 days & 170 & I 80 & $I I \cdot O$ & $12 \cdot 0$ & 19 & I 8 & $14 \cdot 8$ & $14 \cdot 0$ & 42 & 25,770 & 27,190 \\
\hline Simoni & 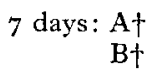 & $\begin{array}{l}152 \\
151\end{array}$ & $\begin{array}{l}\text { I } 54 \\
\text { I } 54\end{array}$ & $\begin{array}{l}11 \cdot 6 \\
10 \cdot 7\end{array}$ & $\begin{array}{l}9^{*} 9 \\
9^{\cdot} 9\end{array}$ & $\begin{array}{l}19 \\
\text { I } 8\end{array}$ & $\begin{array}{l}18 \\
\text { I } 8\end{array}$ & $\begin{array}{l}\text { I } 4.0 \\
\text { I } 3.4\end{array}$ & $\begin{array}{l}14.0 \\
14.0\end{array}$ & $\begin{array}{l}31 \\
29\end{array}$ & 19,900 & $\underline{22,750}^{\circ}$ \\
\hline Mariko & 7 days: $\begin{array}{r}A \dagger \\
B \dagger\end{array}$ & $\begin{array}{l}163 \\
\times 63\end{array}$ & $\begin{array}{l}178 \\
178\end{array}$ & IO.O & $12 \cdot 3$ & 17 & I9 & $13 \cdot 0$ & $14^{\circ} \mathrm{O}$ & $3 x$ & 22,990 & $\stackrel{24,870}{-}^{-}$ \\
\hline Simoni & $\begin{array}{l}\text { Sum of } \\
\text { four } 96 \mathrm{~h} \\
\text { periodst }\end{array}$ & 264 & 266 & 19.0 & 15.0 & 30 & 32 & - & - & - & - & - \\
\hline
\end{tabular}

* In calculating from tables the figure 5.3 Cal./g was used for the calorie value of protein (see p. 2 ro).

$+\mathrm{A}$ and $\mathrm{B}$ are the results of determinations on separate food packs (see p. 206).

1 Sum of four $96 \mathrm{~h}$ periods ( 6 days in all). At that time the food samples were obtained by reserving a onetenth portion of all meals and drinks. Neither potassium nor calcium was estimated in food, as in other experiments, nor were calorie values of food or excreta determined.

was rejected on account of poor agreement between the values for total nitrogen found in the food and those calculated from the tables.)

It will be noted that all the subjects were in positive nitrogen balance, Simoni's retention being the least, $4.8 \mathrm{~g} /$ day, and Kibenje's the greatest, $12 \mathrm{~g} /$ day. Unfortunately, Simoni's total urinary sulphur determination was lost. All the other subjects were in positive sulphur balance, and in the other experiment on Simoni, which was rejected for reasons given above, the sulphur balance was $+\mathrm{I} \cdot \mathrm{I} \mathrm{g}$. We have little doubt but that he too was in positive sulphur balance during the period of the second experiment. The phosphorus balances as shown in Table 6 are the differences between total intake and total output. However, we were interested in the phosphorus available for the building of soft tissues rather than in total phosphorus retention. In order to calculate this value, the calcium balance was also determined. On the assumption that the retention of three atoms of calcium will require two atoms of phosphorus to form $\mathrm{Ca}_{3}\left(\mathrm{PO}_{4}\right)_{2}$, the overall phosphorus retention can be corrected to give the amount available for tissues other than bone. This amount is shown in Table 8 . On both occasions Kibenje showed a positive potassium balance, but the potassium balance was negative in both Simoni and Mariko. In all four experiments $90 \%$ or more of the total food calories were absorbed. We should point out that the figures for calories are those actually measured in the bomb calorimeter. In the calorimeter nitrogen is converted into $\mathrm{NO}_{2}$, but in the body it is converted into urea. However, as the urinary urea nitrogen is also oxidized to $\mathrm{NO}_{2}$ in the bomb, the difference between the measured calorie values of the food and excreta will still represent the calories absorbed, and a true percentage absorption will be obtained. The values obtained for the food agreed 


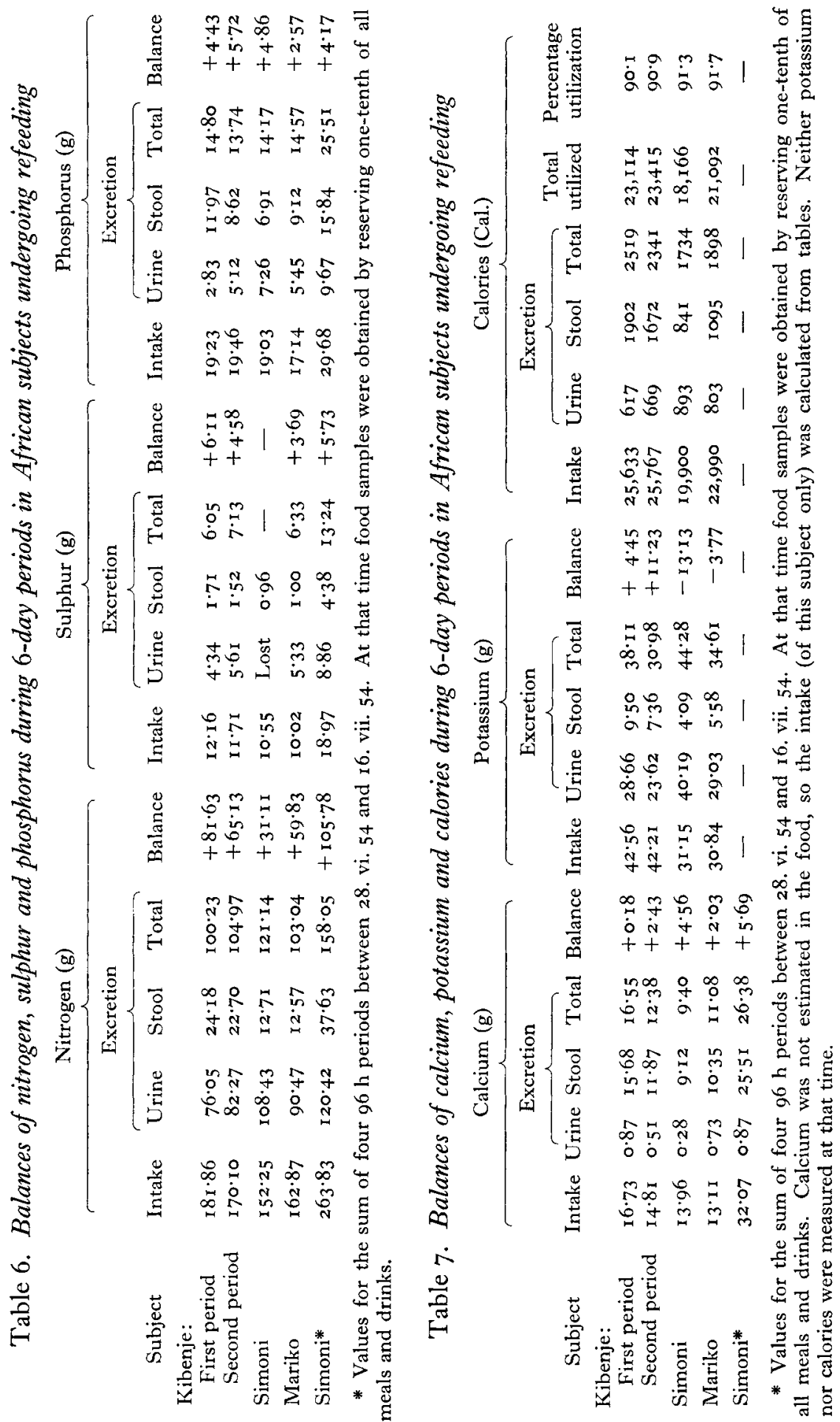


reasonably with, though they were somewhat lower than, those obtained by calculation from the food tables, when the figure 5.3 instead of 4.0 was used for calculating the calorie value of protein (see Table 5). The absorption observed ( $90 \%$ of the calories consumed) shows that there was no defect in the power of absorption of our subjects on the ward diet. This measure affords us no information about their powers of absorption on their accustomed diet. Our subjects, moreover, had all been some months in the ward and had shown great clinical improvement since admission. It does not follow that their absorption was equally good during the early stages of their condition.

Table 8. Nitrogen, sulphur and phosphorus retention (values and ratios) of African subjects during refeeding

\begin{tabular}{|c|c|c|c|c|c|}
\hline Subject & $\begin{array}{l}\text { Nitrogen } \\
\text { retained } \\
(\mathrm{g})\end{array}$ & $\begin{array}{l}\text { Sulphur } \\
\text { retained } \\
\text { (g) }\end{array}$ & $\begin{array}{l}\text { Phosphorus } \\
\text { retained in } \\
\text { tissues other } \\
\text { than bone* } \\
\text { (g) }\end{array}$ & $\begin{array}{c}\text { Ratio, } \\
N: S\end{array}$ & $\begin{array}{c}\text { Ratio, } \\
N: P\end{array}$ \\
\hline Simoni & $3^{x \cdot 1}$ & - & 2.5 & - & 12 \\
\hline $\begin{array}{l}\text { Kibenje: } \\
\text { First period } \\
\text { Second period }\end{array}$ & $\begin{array}{l}8 \mathrm{I} \cdot 6 \\
65 \cdot \mathrm{x}\end{array}$ & $\begin{array}{l}6 \cdot I \\
4 \cdot I\end{array}$ & $\begin{array}{l}4 \cdot 3 \\
4 \cdot 5\end{array}$ & $\begin{array}{l}\text { I3 } \\
\text { I6 }\end{array}$ & $\begin{array}{l}19 \\
15\end{array}$ \\
\hline Mariko & $59 \cdot 8$ & $6 \cdot 0$ & $I \cdot 5$ & ro & 40 \\
\hline Simoni & $105.8 \dagger$ & $5.7 \dagger$ & $2 \cdot 2 \dagger$ & I 8 & 48 \\
\hline
\end{tabular}

Table 8 shows the nitrogen:sulphur and nitrogen:phosphorus ratios obtained in these experiments. One N:S value for Simoni is omitted for reasons already given. The values for phosphorus retained have been corrected for calcium retention, as explained (see p. 208). We have not ourselves carried out any determinations of total phosphorus in human tissues; the values given in the literature vary within"very wide limits. Since the sulphur content of different proteins varies much more widely than does their nitrogen content, different tissues may be expected to have a different $N: S$ ratio roughly in accordance with the make-up of the protein which predominates in their composition. The following $\mathrm{N}: \mathrm{S}$ ratios can be calculated from the data of Block $\&$ Bolling (1947): entire animal ${ }_{3} 3^{\circ}$, skin and hair $3 \cdot 5$, haemoglobin $30^{\circ} 3$, serum proteins $\mathrm{i} \cdot 8$, muscle $16 \cdot 3$, elastin I $15^{\circ}$. The $\mathrm{N}: \mathrm{S}$ ratios in Table 8 would be compatible with the manufacture of muscle tissue, together with a certain amount of other tissue having a lower $\mathrm{N}: \mathrm{S}$ ratio, e.g. skin.

It was mentioned earlier (p. 206) that higher values for total sulphur in urine were obtained when the urine was dried at $70^{\circ}$ than when it was dried at $110^{\circ}$. The peroxidebomb method is applicable only to solids, so that the urine had to be evaporated before estimation. The possibility that sulphur may be lost by heating urine to $110^{\circ}$ is of some interest since, so far as we know, all the methods for measurement of total sulphur involve violent heating, and only if a bomb is used would the loss of volatile 
compounds be avoided. This observation led us to freeze-dry the urine. For Kibenje, the neutral sulphur formed a considerably greater proportion of the total urinary sulphur so determined than the generally accepted figure of $10 \%$ or less. We have not: so far, had the opportunity to pursue this matter further. Table 9 shows the results obtained.

Table 9. Distribution of sulphur excretion during balance periods by African subjects undergoing refeeding

\begin{tabular}{|c|c|c|c|c|c|c|}
\hline \multirow[b]{2}{*}{ Subject } & \multicolumn{3}{|c|}{ Urinary sulphur } & \multirow[b]{2}{*}{$\begin{array}{l}\text { Faecal } \\
\text { sulphur } \\
\quad(g)\end{array}$} & \multirow[b]{2}{*}{$\begin{array}{l}\text { Total } \\
\text { sulphur } \\
\text { excreted } \\
\text { (g) }\end{array}$} & \multirow[b]{2}{*}{$\begin{array}{l}\text { Neutral } \\
\text { sulphur as } \\
\text { percentage of } \\
\text { total urinary } \\
\text { sulphur }\end{array}$} \\
\hline & $\begin{array}{c}\text { Inorganic } \\
\text { and } \\
\text { ethereal } \\
\text { (g) }\end{array}$ & $\begin{array}{c}\text { Neutral } \\
(\mathrm{g})\end{array}$ & $\begin{array}{c}\text { Total } \\
\text { (g) }\end{array}$ & & & \\
\hline Simoni & $6 \cdot 39$ & 0.66 & 7.05 & $1 \cdot 12$ & $8 \cdot 17$ & $9 \cdot 3$ \\
\hline $\begin{array}{l}\text { Kibenje: } \\
\text { First period } \\
\text { Second period }\end{array}$ & $\begin{array}{l}3.52 \\
3.88\end{array}$ & $\begin{array}{l}0.82 \\
1.73\end{array}$ & $\begin{array}{l}4.34 \\
5.6 r\end{array}$ & $\begin{array}{l}I \cdot 71 \\
x \cdot 52\end{array}$ & $\begin{array}{l}6.05 \\
7.13\end{array}$ & $\begin{array}{l}18 \cdot 9 \\
30.8\end{array}$ \\
\hline Mariko & $4 \cdot 6 \mathrm{I}$ & 0.72 & $5 \cdot 33$ & r. & $6 \cdot 33$ & $\mathrm{r} 3.5$ \\
\hline
\end{tabular}

A number of separate determinations of inorganic and of inorganic and ethereal sulphates on these and other subjects showed the usual small proportion of ethereal sulphate, and need not be given in detail.

One other subsidiary point emerged from these experiments. It was thought to be of interest to compare the total observed calorie value of the urine with the value calculated from the organic constituents which could be readily estimated and which we supposed to contribute between them the bulk of the urinary calories. Thus creatine + creatinine, uric acid, amino and ammonia nitrogen, ammonia (and so by difference amino-nitrogen) were determined, and the difference between the total nitrogen and the sum of the nitrogen of the constituents just mentioned was taken to be urea nitrogen. None of the urine samples contained sugar, albumin, or bile pigments in abnormal amounts. Table to shows the results obtained; there was a very considerable calorie deficit, indicating that the calorie value of the urine was considerably greater than that contributed by the substances measured. There are of course a

Table ro. Comparison of calorie value of urine in African subjects with that calculated from values for urinary constituents

\begin{tabular}{|c|c|c|c|c|c|c|c|c|c|c|}
\hline \multirow[b]{3}{*}{ Subject } & \multirow[b]{3}{*}{ Date } & ulat & rom & Jor & rinary & onsth & $n t s$ & \multicolumn{3}{|c|}{ Calorie value of urine } \\
\hline & & \multicolumn{2}{|c|}{ Urea nitrogen } & \multicolumn{2}{|c|}{$\begin{array}{l}\text { Uric-acid } \\
\text { nitrogen }\end{array}$} & \multicolumn{2}{|c|}{$\begin{array}{l}\text { Creatinine } \\
\text { nitrogen }\end{array}$} & \multirow{2}{*}{$\begin{array}{l}\text { Calcu- } \\
\text { lated } \\
\text { (Cal.) }\end{array}$} & \multirow{2}{*}{$\begin{array}{l}\text { Found } \\
\text { (Cal.) }\end{array}$} & \multirow{2}{*}{$\begin{array}{l}\text { Unac- } \\
\text { counted } \\
\text { for } \\
\text { (Cal.) }\end{array}$} \\
\hline & & $\mathrm{g}$ & Cal. & $\mathrm{g}$ & Cal. & $\mathrm{g}$ & Cal. & & & \\
\hline Simoni & $\begin{array}{l}\text { 28. iii. } 55^{-} \\
\text {3. iv. } 55\end{array}$ & $9 r \cdot 2$ & 495 & $0.9 \mathrm{I}$ & 7 & $10 \cdot 7$ & 144 & 646 & 896 & 250 \\
\hline $\begin{array}{l}\text { Kibenje: } \\
\quad \text { First period }\end{array}$ & $\begin{array}{l}\text { 25. i. } 55^{-} \\
\text {I. ii. } 55\end{array}$ & $67 \cdot 2$ & $3^{6} 5$ & $x \cdot x 6$ & ro & $6 \cdot 1$ & 82 & 457 & 617 & 160 \\
\hline Second period & $\begin{array}{l}\text { 4. ii. } 55^{-} \\
\text {II. ii. } 55\end{array}$ & $70 \cdot 4$ & 390 & $I \cdot I 6$ & 10 & $7 \bullet 4$ & 99 & 499 & 669 & 170 \\
\hline
\end{tabular}


number of urinary pigments present in unknown amounts and our subjects appeared to excrete some unidentified sulphur-containing substance. It should be pointed out that it cannot be an amino-acid, since the ammonia nitrogen was always almost equal to the amino + ammonia nitrogen. If protein was being synthesized a very low figure for urinary amino-acids would be expected.

\section{PAR'T 3. THE COMPOSITION OF MUSCLE}

We would have wished to present evidence of the actual composition of the tissues of our subjects before and after feeding on the high-protein, high-calorie diet, but this we have been unable to do. It was quite impossible to obtain biopsy specimens of muscle with the consent of the patients, and to endeavour to perform biopsies under the guise of a therapeutic procedure would have resulted only in their absconding from hospital.

To obtain material we were forced to use specimens of muscle obtained at autopsy or operation. Subjects in a condition similar to those whom we have studied soon after admission to hospital sometimes come to autopsy but seldom to operation, since they are manifestly poor surgical risks. Our specimens of muscle were therefore obtained from the general run of patients coming to operation, and we have tried on an assessment of their dietary history to divide them into three groups: nutrition good, nutrition doubtful and nutrition poor.

\section{EXPERIMENTAL}

The tissue, obtained in the mortuary or operating theatre was placed immediately after removal in a Petri dish containing some moist filter-paper to prevent evaporation. It was taken immediately to the laboratory. Blood, if present, was wiped off and fat or tendon removed. The tissue was placed in a tared weighing bottle and dried at $90^{\circ}$ to constant weight. The dried material was ground in a mortar with a pestle. Total nitrogen was estimated in one portion; another was extracted by grinding three times with small quantities of $15 \%$ trichloroacetic acid and non-protein nitrogen was determined in the filtrate. All the nitrogen measurements were by the Kjeldahl method.

From these determinations we obtained values for water, protein, and non-protein solids. The last are chiefly fat and lipids, but also include small amounts of glycogen, organic phosphorus compounds and ash.

\section{RESULTS}

Table I I shows the results. It will be observed that the differences between the mean values for the three groups are not statistically significant. Probably none of the subjects was truly representative of the group which we previously studied soon after admission to hospital. It is not possible to get sufficiently accurate information about previous diets to make valid the distinction which we have sought to draw.

A rather different picture is obtained if we treat all our subjects as a single group, and compare the results obtained for them with the data on the constitution of muscle published by other workers. Bien, Ziff \& Bunim (I95I) carried out a series of biopsies on normal persons, persons suffering from arthritic complaints and persons suffering 
Table I. Analysis of muscle of African adults

Composition of muscle ( $\mathrm{g} / \mathrm{r} 00 \mathrm{~g}$ fresh muscle)

Subject

$\overbrace{\text { Sex Diagnosis }}^{\text {Subject }}$

\author{
Muscle \\ Source* and type
}

Non- Nonprotein protein

Water Solids Protein nitrogen solids

Subjects whose nutrition was classified as poor

M. Hookworm and malnutrition

$\begin{array}{lll}\text { PM Biceps } & 79.4 & 20.6\end{array}$

M. Postnecrotic scarring, liver

M. Tubercular hip

M. Tubercular thoracoplasty

M. Carcinoma, colon

M. Lobar pneumonia

M. Abdominal haemorrhage

F. Lobar pneumonia

M. Pneumonia and pleural effusion

M. Splenectomy

M. Tuberculosis

Mean
PM Rectus abdominis

OP Gluteus maximus

$\mathrm{OP}$ Intercostal

OP Rectus abdominis

PM Rectus abdominis

PM Rectus abdominis

PM Rectus abdominis

PM Gastrocnemius

OP Rectus abdominis

PM Quadriceps
$80.8 \quad 19 \cdot 2$

$76 \cdot 5 \quad 23 \cdot 5$

$73 \cdot 0 \quad 27.0$

$77 \cdot 8 \quad 22 \cdot 2$

$79^{\circ} \mathrm{O} \quad 21 \cdot 0$

$79 \cdot 8 \quad 20 \cdot 2$

$82 \cdot 9 \quad 17 \cdot 1$

$78 \cdot 9 \quad 2 \mathrm{I} \cdot \mathrm{I}$

$79 \cdot 3 \quad 20 \cdot 7$

$78 \cdot 2 \quad 21 \cdot 2$
$79 \cdot 7 \quad 20 \cdot 3$

$\begin{array}{ccc}\text { I5.2 } & 0.12 & 5.4 \\ & & \\ \text { I5.1 } & 0.16 & 4.1 \\ & & \\ \text { I4.1 } & 0.04 & 9.4 \\ \text { I7.1 } & 0.12 & 9.9 \\ & & \\ \text { I6.9 } & 0.08 & 3.4 \\ 12.5 & 0.13 & 9.7 \\ \text { I4.0 } & 0.13 & 7.9 \\ & & \\ \text { I4.0 } & 0.14 & 6.2 \\ 12.3 & 0.08 & 4.8 \\ & & \\ 14.9 & 0.15 & 6.2 \\ 16.7 & 0.15 & 4.0 \\ 14.8 & 0.12 & 6.5\end{array}$

Subjects whose nutrition was classified as doubtful

M. Endomyocardial fibrosis

F. Hypertensive heart failure

M. Anuria due to sulphonamide

M. Acute focal necrosis of liver

M. Lobar pneumonia

M. Lobar pneumonia Mean

PM Rectus abdominis
PM Rectus abdominis
PM Pectoralis

PM Rectus abdominis

PM Rectus abdominis

PM Rectus abdominis

$\begin{array}{lllll}82.2 & 17.8 & 14.8 & 0.12 & 3.0 \\ 83.1 & 16.9 & \text { I5.3 } & 0.13 & \text { I.6 } \\ 79.5 & 20.5 & 15.2 & 0.12 & 5.3 \\ 77.8 & 22.2 & 9.6 & 0.11 & 12.6 \\ 77.8 & 22.2 & 17.5 & 0.17 & 4.7 \\ 75.4 & 24.6 & 20.0 & 0.16 & 4.6 \\ 79.3 & 20.7 & 15.4 & 0.13 & 5.3\end{array}$

Subjects whose nutrition was classified as good

M. Not recorded

M. Thoracoplasty

M. Arthrodesis, knee

M. Fractured femur

M. Epithelioma; amputation, foot

M. Tropical ulcer; lumbar sympathectomy

M. Amputation, arm

M. Compound fracture ; amputation, leg

M. Gangrene; amputation, leg

M. Laceration, wrist

F. Fractured femur

Mean

Mean and standard deviation for all subjects

OP Pectoralis

OP Quadriceps

OP Quadriceps

OP Tibialis

OP Biceps

OP Quadriceps

OP Quadriceps

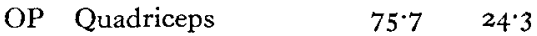

$75^{\circ} 9 \quad 24^{\circ} x$

$70.4 \quad 29 \cdot 6$

$77 \cdot 6 \quad 22 \cdot 4$

$77 \cdot 4 \quad 22 \cdot 6$

$77 \cdot 7 \quad 22 \cdot 3$

$78 \cdot 4 \quad 21 \cdot 6$

$76 \cdot 7 \quad 23 \cdot 2$

$82.7 \quad 17 \cdot 3 \quad 10 \cdot 1$

$20 \cdot 6$

$17 \cdot 2$

$16 \cdot 0$

$16 \cdot 5$

13.0

0.08

0.14

0.20

0.13

0.07

15.8

$0 \cdot 10$

OP Gastrocnemius

PM Sternomastoid

$80 \cdot 8$

$19.2 \quad 12.0$

$78 \cdot 3 \quad 21 \cdot 7 \quad 13.4$

$77 \cdot 4 \quad 22 \cdot 6 \quad 14 \cdot 8$

$78 \cdot 4 \pm \quad 21 \cdot 6 \pm \quad 14.9 \pm$

$\begin{array}{lll}2.85 & 2.85 & 2.50\end{array}$

0.21

0.22

O.I $2 \quad 7 \cdot 2$

$0.07 \quad 7.2$

$0.17 \quad 8.3$

$0.14 \quad 7.7$

$0.13 \pm 6.7 \pm$ $0.04 \quad 2.73$

* PM, post-mortem; OP, operation. 
from miscellaneous diseases. Their data for water content and protein as a percentage of dry weight can be recalculated as shown in Table 12 . The data do not permit of the calculation of the standard deviation of the figures.

Table I2. Data of Bien et al. (195I) for composition of muscle recalculated for comparison with present findings ( $\mathrm{g} / \mathrm{I} 00 \mathrm{~g}$ fresh muscle)

\begin{tabular}{lccc} 
& \multicolumn{3}{c}{ Muscle composition } \\
No. and condition of subjects & Water & Protein & $\begin{array}{c}\text { Non-protein } \\
\text { solids }\end{array}$ \\
6, normal & 77.3 & 16.62 & 6.08 \\
3, with doubtful muscle lesions & 77.9 & 15.61 & 6.50 \\
3, with definite muscle lesions & 78.6 & 16.03 & 5.37 \\
8, with miscellaneous diseases & 68.6 & 16.05 & 7.35 \\
$\quad$ Weighted mean & 76.3 & 16.15 & 6.54
\end{tabular}

Localio, Chassin \& Hinton (1948) have compared the protein content of biopsy specimens of muscles, fascia and peritoneum of normal patients coming to operation, of those debilitated by prolonged illness before operation and of those who suffered from postoperative wound disruption. The dry weight of the tissues was not determined, so that no figures are available for non-protein solids or water. They found the protein content of normal muscle (rectus abdominis) of seventeen subjects to be $19 \cdot 35 \pm 2 \cdot 26 \mathrm{~g} / \mathrm{ro0} \mathrm{g}$ fresh weight (mean value and standard deviation).

Talso, Spafford \& Blaw (1953) give figures for the water, total nitrogen, potassium, sodium chloride, and ether-soluble material of biopsy specimens of the muscle of sixteen normal subjects. From these data, by assuming a non-protein nitrogen content of $0.13 \mathrm{~g} / 100 \mathrm{~g}$ fresh tissue (our own value), it has been possible to calculate the water, protein and non-protein solids of their subjects, and the mean value and standard deviation are as follows: protein, $16 \cdot 93 \pm \mathrm{x} \cdot 63$; water, $77 \cdot 66 \pm 6 \cdot 4$; non-protein solids, $5 \cdot 70 \pm \mathrm{I} \cdot 68$.

If we compare these results with our own, the following points emerge:

(I) There was no significant difference between the water content observed by us and by any of the other authors (our figures $78 \cdot 4 \pm 2 \cdot 85$; Bien et al. (I95I) $76 \cdot 3$; 'Talso et al. (1953) $77 \cdot 66 \pm 6 \cdot 4)$.

(2) The protein content of the muscles of our subjects was significantly lower than that of any of the other groups reported. Thus, if we compare the protein content ( $g$ protein/roog fresh muscle) of the muscles of our subjects with that found by the authors quoted above, we obtain the results shown in Table 13 .

Table 13. Comparison of present results for protein content of muscle with those of other workers (g protein/1oog fresh muscle)

\begin{tabular}{lccc}
\multicolumn{1}{c}{$\begin{array}{c}\text { Reference } \\
\text { subjects }\end{array}$} & $\begin{array}{c}\text { Mean value with } \\
\text { standard deviation }\end{array}$ & $t$ \\
Present series & 28 & $14.94 \pm 2.50$ & - \\
Bien et al. (195I) & 20 & 16.15 & $\begin{array}{c}\text { Cannot be } \\
\text { calculated }\end{array}$ \\
Localio et al. (1948) & I7 & $19 \cdot 35 \pm 2.26$ & $6 \cdot 1$ \\
Talso et al. (1953) & I5 & $16.93 \pm 1.63$ & $3 \cdot 2$
\end{tabular}


(3) The percentage of the non-protein solids of the muscles of our subjects $(6 \cdot 72 \pm 2.73 \mathrm{~g} / 100 \mathrm{~g}$ fresh muscle) differed little from that of the subjects studied by Bien et al. $(6.54)$. It was greater than in the subjects studied by Talso et al. $(5 \cdot 70 \pm \mathrm{I} \cdot 68)$, but the difference was not statistically significant for these numbers $(t=\mathrm{r} \cdot 55)$.

It appears, therefore, that the muscles of the subjects studied by us contained significantly less protein than those recorded in the literature. The difference must have been made up either by their having a greater content of water, or by a greater content of non-protein solids, or both.

\section{DISCUSSION}

The three parts of this paper are discussed together, since they represent attempts to solve a single problem by three different methods of approach. The problem, briefly, is what is the composition, in terms of cell mass, extracellular fluids and minerals, of the body of African subjects who have lived on a diet grossly deficient in protein, and how is it modified by feeding on a high-protein, high-calorie diet?

We have approached the question first by using one of the standard methods of determining body composition, involving the determination of total body water with urea, and of extracellular water with thiocyanate. Like all the other methods so far available, these methods are open to criticism. Nevertheless, the results obtained by their use seem, from the literature, to be at least as satisfactory, when applied to normal and malnourished subjects, as any of the others. In our hands they have given results which appear quite reasonable for both European and African controls and for our malnourished subjects after rehabilitation. However, when the methods were applied to these subjects soon after admission to the ward the results indicated that for some of these patients the methods are subject to technical or theoretical fallacy. For two subjects the sum of the extracellular fluid, apparent cell mass and minerals was considerably greater than the body-weight, and for a third, this figure was almost equal to it (thus erroneously indicating a fat-free body).

It will be recalled that the urea was given intravenously, so that no question of failure in its absorption arises. The validity of the method depends on the assumption that urea is evenly distributed throughout the body fluids. There is no way of checking that this is in fact so. If, however, a distribution were incomplete at the time that the final blood sample was taken, the final blood urea would presumably be too high. This would result in an erroneously low figure for total body water, and so too low a figure for cell mass. This value, in turn, would give a figure for fat which erred in being too high, not too low as we found. Our results suggest that the figure for cell mass may be exaggerated and, therefore, the figure for fat too low. Since, moreover, exactly the same technique was used in determinations on the controls as on the subjects before and after refeeding, there seem to be no grounds for postulating either a technical error in the estimation of urea, or a failure to allow time for diffusion of urea throughout the body fluid. Urea presumably passes into the bowel from the blood stream. No correction can be made for loss of urea in this way. Such loss would falsify the figure for urea remaining (excess of urea injected minus urea excreted, over the basal 
value). An error of this kind would tend to produce too high a figure for total body water and hence too large a figure for cell mass. We do not know, however, of any reason why urea should be more rapidly excreted into the bowel in our subjects in the early stages, than in the controls, or in the same subjects at a later date.

Apart from the question of technical error, there is, as was indicated in Part I, the possibility of a theoretical fallacy. The cell mass is calculated by assuming that the cell water (total body water less extracellular water) represents $67 \%$ of the cell mass. If, however, the cells should contain an appreciably greater proportion of water the use of a figure of $67 \%$ will give an erroneously high figure for cell mass. It will also entail an exaggeration of the figure for minerals (which is taken as $7.5 \%$ of the cell mass and the extracellular fluid) and might make the sum of the cell mass, extracellular fluid and minerals equal to, or greater than, the body-weight. It would, in fact, explain the anomalous results described in this paper and also could help to explain the discrepancy between tissue gain calculated from observed nitrogen retention and change in body-weight previously noted by us (Holmes et al. I954), since synthesized protein would replace water in the protein-depleted cells.

The question could be directly resolved if there were available an independent method for the determination of fat in human subjects. However, the densitometric method involves an assumption about the water content of fat-free tissues. It also seems unlikely that a skinfold method would be adequate. It has not yet been established that a strict relationship exists between subcutaneous fat and fat in the fat depots, and it seems certain that oedema of the subcutaneous tissue would invalidate any method based on measurements of the thickness of folds of skin.

For a young growing organism in positive nitrogen balance there is the possibility of an increase in the number of cells in a tissue; but there is little evidence that this increase occurs in adult life. For an adult subject in positive nitrogen balance two theoretical possibilities exist; he may increase the size of the tissue cells, keeping their composition constant, or he may increase the concentration of protein within a cell-which would imply an alteration in cell composition with respect to percentages of water and protein. There is already evidence that in some circumstances the water content of the cells may vary. Such variation is the explanation offered for their results by Gopalan, Venkatachalam \& Srikantia (1953); these results, which appeared in part in a report from the Nutrition Research Laboratories, Coonoor (1954) have been referred to in Part I. Passmore, Meiklejohn, Dewar \& Thow (I955 $a, b$ ) have found that their adults fed on a high-calorie, high-protein diet, retained protein and fat, but that their gain in body-weight allowed no margin for a simultaneous retention of water. They suggested that the water content of cells may be variable even in health, so that no normal cell composition can be defined.

Since we have at present no direct method of distinguishing the two possibilities, we have endeavoured to make use of an indirect one, the theory of which was outlined in the introduction to Part 2. If in severe malnutrition cells contain abnormally large quantities of water and abnormally small quantities of protein and if, as a result of protein feeding, the protein content increases and the water content falls, it seems to us that the potassium content of the cells might also diminish. Thus, though an orga- 
nism that is increasing either the number or size of cells of normal composition must retain both potassium and protein, an organism that is increasing the protein content of its cells will not need to retain potassium in the same proportion as it retains protein. In these circumstances there may be an overall positive nitrogen balance with a potassium balance smaller than would be expected from the nitrogen retained, or even negative. To test this possibility we have carried out simultaneous potassium and nitrogen balances on three of our subjects. In two (Simoni and Mariko) of the three there was a positive nitrogen balance with a negative potassium balance; this finding is compatible with the hypothesis just described. We do not suggest, of course, that this crude hypothesis gives a complete picture of what is occurring in the cells during the deposition of fresh protein, if this indeed is taking place. If the cells are losing water, it is reasonable to suppose that they are also losing potassium salts, otherwise, presumably, the osmotic conditions within the cell would be disturbed. But the cell could lose potassium only if accompanied by some negatively charged ion, and one would at first sight expect a negative potassium balance to be accompanied by a negative phosphorus balance as phosphate is the anion present in highest concentration in the intracellular fluid. In fact, in the two subjects under consideration there was a positive balance of phosphorus, after allowance had been made for retention of phosphorus corresponding to the retention of calcium. Increase in tissue protein might be supposed to involve retention of phosphorus both as a constituent of nucleoprotein, and of those organic compounds of phosphorus involved in cell function. If phosphate is retained in the cell some positively charged ion, other than potassium, must have been retained also (in our subjects). The observation (Eckel \& Norris, 1955) that potassiumdepleted rats show an increase in their muscles of the strongly basic amino-acid, lysine, may prove to be of interest in this connexion.

Our third subject (Kibenje) on whom balance experiments were carried out showed a retention of potassium as well as of nitrogen. This man's apparent age was 16 or 17 years, so that he was still in the period of growth. The balance experiments were included in the period between the first and second determinations of body composition. During I 12 days his weight had increased by $8 \cdot 1 \mathrm{~kg}$, and his apparent cell mass by $8.0 \mathrm{~kg}$. We suppose that here we had to do with the metabolic phenomenon of normal growth, though accelerated by a period of lavish diet after a period in which the diet had been poor. New formation of normal cells would require the retention of both nitrogen and potassium.

In general, the experiments described in Parts I and 2 led us to the suggestion that our adult subjects undergoing refeeding after malnutrition showed extreme variations in cell composition, and that such extreme variations may represent a morbid condition. When we first undertook the experiments described in Part 3 of this paper, we hoped to be able to demonstrate directly that the muscles of these subjects contained more water and less protein when they first came under observation than they did after refeeding. It soon became obvious, however, that such a demonstration was impracticable for the reasons stated earlier (p. 212 ). We did find, however, a suggestion that the muscle specimens which we were able to obtain contained less protein than found in normal persons by other workers in other parts of the world: the difference 
was evidently made up partly by water, partly by non-protein solids which may have been chiefly fat.

We had always supposed that during refeeding fat might be lost as protein was laid down. A protein-rich diet has for long been used in the treatment of obesity; autopsies performed on subjects in a condition similar to those studied by us (before refeeding) often reveal considerable amounts of fat in the usual situations. Therefore, we have always kept in mind the possibility that replacement of fat as well as of water by protein might partly account for the failure of our subjects to show a gain in weight corresponding to the protein storage calculated from the nitrogen retention.

There remains to mention briefly the apparent effect of cortisone on body composition recorded in Part I (Table 4). This finding was accidental in the sense that ACTH and cortisone were given in order to observe their effect on an unexplained eosinophilia which occurred in several subjects, Simoni among others. It happened that determinations of body composition were carried out soon after the administration of the hormones, and the subsequent determinations were made in order to follow up the matter. These hormones are well known to alter extracellular fluid, but the effect is transitory and should have long disappeared by the time the observations recorded in the table were made. The chief effect here observed was on total body water and therefore on body solids. It is of course known that cortisone increases the excretion of nitrogenous compounds including creatinine and uric acid; presumably, therefore, it stimulates a breakdown of cell protein. In our previous experiments on nitrogen balance it was only by the use of cortisone that we could obtain negative balances in our subjects on the high-protein, high-calorie diets (Holmes et al. 1954). If our previous arguments are correct, cortisone has produced a condition of cell hydration comparable to that in some of the subjects referred to in Part $\mathrm{x}$ (Table 3). Experiments to follow up this question will be undertaken.

\section{SUMMARY}

I. Body composition was studied by the method of McCance \& Widdowson (I95 I) in thirteen normal European and African subjects, and in eight malnourished African patients before and after treatment on a high-protein, high-calorie diet. The patients had high values for total body water, and most for thiocyanate space also, before treatment; these values approached normal during treatment. A series of six determinations of body composition was made on one patient who received, in addition to the dietary treatment, ACTH and cortisone. These compounds appeared to increase his intracellular water. The validity of the method for determination of body composition is discussed. It is suggested that in certain circumstances there may be a severe hydration of the tissue cells.

2. Balance experiments for nitrogen, sulphur, phosphorus, calcium, potassium and calories were performed for five periods on three patients undergoing dietary treatment for malnutrition. The calorie balances indicated that in all subjects over $90 \%$ of the dietary calories were absorbed. There was a positive balance of sulphur and phosphorus as well as of nitrogen; it gave additional evidence that the prolonged nitrogen storage previously observed in such subjects was in fact due to protein synthesis. In the two 
adult patients there was a negative potassium balance. The significance of a negative potassium balance in the presence of a positive nitrogen balance is discussed; and it is suggested that in pathological conditions tissue cells may vary in composition.

3. Determinations were made of the water, protein and non-protein nitrogen content of muscle samples taken at operation or autopsy from twenty-eight African subjects suffering from a variety of diseases. The subjects available did not exactly correspond clinically to the subjects of the observations mentioned above. Their muscles contained less protein than is reported by other workers for subjects in America. The difference was made up partly by water, partly by non-protein solids.

We record our gratitude to the Medical Superintendant, Mulago Hospital, for facilities; to Professor Williams and Drs Trowell and Hutton for transferring patients; to Professors Croot and Davies and their colleagues for providing muscle samples; to $\mathrm{Mr} \mathrm{H}$. E. Benton for much technical assistance, and to $\mathrm{Mr}$ John Kyobe for help in many ways.

\section{REFERENCES}

Archibald, R. M. (1943). F. biol. Chem. 157, 507.

Bien, E. J., Ziff, M. \& Bunim, J. J. (195I). Proc. Soc. exp. Biol., N. Y., 76, 649.

Block, R. J \& Bolling, D. (1947). The Amino Acid Composition of Proteins and Foods, ist ed., 2nd printing. Springfield, Ill.: C. C. Thomas.

Brodie, B. B., Brand, E. \& Leshin, S. (1939). F. biol. Chem. r3o, 555.

Cardozo, R. H. \& Edelman, I. S. (1952), F. clin. Invest. 31, 280.

Chemical Rubber Publishing Company (1949). Handbook of Chemistry and Physics, 3 ist ed. Cleveland, Ohio: Chemical Rubber Publishing Co.

Cole, S. W. (1928). Practical Physiological Chemistry. Cambridge University Press.

Deane, N., Schreiner, G. E. \& Robertson, J. S. (195 I). F. clin. Invest. 30, 1463.

Eckel, R. C. \& Norris, J. C. (1955). F. clin. Invest. 34, $93 \mathrm{I}$.

Edelman, I. S., Olney, J. M., James, A. H., Brooks, L. \& Moore, F. D. (I952). Science, Ir5, 447.

Fox, F. W. \& Goldberg, L. (1944). Publ. S. Afr. Inst. med. Res. 9, 123.

Frazer, A. C., French, J. M., Thomas, A. \& Thompson, M. D. (1952). Clin. Sci. II, I41.

Gaudino, M., Schwartz, I. L. \& Levitt, M. F. (1948). Proc. Soc. exp. Biol., N.Y., 68, 507.

Gopalan, C., Venkatachalam, P. S. \& Srikantia, S. F. (1953). Metabolism, 2, 235.

Hawk, P. B. \& Bergeim, O. (1926). Practical Physiological Chemistry, 9th ed. London: J. and A. Churchill.

Hevesy, G. \& Hofer, E. (1934). Nature, Lond., 134, 879.

Holmes, E. G., Jones, E. R. \& Stanier, M. W. (1954). Brit. F. Nutr. 8, 773.

King, E. J. (1951). Micro-analysis in Medical Biochemistry, and ed. London: J. and A. Churchill.

Lavietes, P. H., Bourdillon, J. \& Klinghofer, K. H. (1936). F. clin. Invest. 15, 26 I.

Localio, S. A., Chassin, I. L. \& Hinton, M. D. (1948). Surg. Gynec. Obstet. 86, I07.

McCance, R. A. \& Widdowson, E. M. (1951). Proc. roy. Soc. B, 138, 15.

Masters, M. \& McCance, R. A. (1939). Biochem. F. 33, 1304.

Nutrition Research Laboratories, Coonoor (1954). Rep. Indian Coun. med. Res. Nutr. Res. Lab. Coonoor, I953-4, p. 8.

Odier, J. \& Mach, R. S. (1949). Praxis, 38, 384 .

Pace, N., Kline, L., Schachman, H. K. \& Harfenist, M. (1947). F. biol. Chem. 168, 459.

Passmore, R., Meiklejohn, A. P., Dewar, A. D. \& Thow, R. K. (1955a). Brit. F. Nutr. 9, 20.

Passmore, R., Meiklejohn, A. P., Dewar, A. D. \& Thow, R. K. (1955b). Brit. $尹$. Nutr. 9, 27.

Scheinberg, I. H. \& Kowalski, H. J. (1950). F. clin. Invest. 29, 475.

Soberman, R., Brodie, B. B., Levy, B. B., Axelrod, J., Hollander, V. \& Steele, J. M. (1949). F. biol. Chem. I79, 31 .

Steele, J. M., Berger, E. Y., Dunning, M. F., Brodie, B. B. \& Klein, E. (1950). Amer. F. Physiol. I62, 3I3.

Talso, P. J., Spafford, N. \& Blaw, M. (1953). F. Lab. clin. Med. 4r, 281 .

Widdowson, E. M. \& McCance, R. A. (I95I). In Spec. Rep. Ser. med. Res. Coun., Lond., no. 275, p. 165 . 